\title{
BONE MINERAL STATUS OF YOUNG MEN WITH DIFFERENT LEVELS OF PHYSICAL ACTIVITY
}

\author{
BARBARA DŁUGOŁĘCKA1, EWA JÓWKO', JAN CZECZELEWSKI², \\ IGOR CIEŚLIŃSKI ${ }^{3}$, ANDRZEJ KLUSIEWICZ1
}

\author{
Józef Piłsudski University of Physical Education in Warsaw, Faculty of Physical Education and Sport \\ in Biala Podlaska, Department of Physiology and Biochemistryl, Department of Human Nutrition ${ }^{2}$, \\ Department of Theory and Methodology of Physical Education, Biała Podlaska, Poland
}

Mailing address: Barbara Długołęcka, Józef Piłsudski University of Physical Education in Warsaw, Faculty of Physical Education and Sport in Biala Podlaska, 2 Akademicka Street, 21-500 Biała Podlaska, tel.: +48 83 3428726, fax: +48 83 3428800, e-mail: barbara.dlugolecka@awf-bp.edu.pl

\begin{abstract}
Introduction. The study sought to assess bone mineral content (BMC) and bone mineral density (BMD) in men with different levels of physical activity during the period of reaching peak bone mass. Material and methods. The research included wrestlers $(n=31)$ and students of the University of Physical Education $(n=88)$ aged $18-24$. The state of the bone tissue was assessed with the use of the bone densitometry (DEXA) method (lumbar spine $\mathrm{L}_{2}-\mathrm{L}_{4}$ ). Data concerning the physical activity levels and nutritional behaviours of the study participants were gathered in a diagnostic survey carried out using a specially prepared questionnaire. Results. The analysis of the results revealed that as there were no statistically significant differences in nutritional behaviours between men from particular groups, physical activity proved to be the factor which significantly differentiated the groups under investigation in terms of their bone mass. The highest mean values of the bone parameters analysed were achieved by the wrestlers, who demonstrated a high level of physical activity.
\end{abstract}

Key words: physical activity, peak bone mass, osteoporosis, nutritional behaviours

\section{Introduction}

The majority of studies concerning bone mineral density (BMD) carried out to date have involved women. The rate of bone demineralisation is higher in women than in men, particularly after the menopausal period [1]. However, the studies conducted in recent years have revealed surprising findings regarding the number of bone fractures resulting from osteoporosis in men. Epidemiological studies carried out in Canada revealed that such fractures occurred in $27 \%$ of women and $26 \%$ of men. In Europe, osteoporotic fractures happen every 30 seconds, and their total number exceeds the number of heart attacks or strokes. Osteoporosis is a disease of affluence which affects nearly 3 million people in Poland, including 900,000 men. It was concluded that fractures occurring in men constitute approximately $20-30 \%$ of bone fractures caused by this disease [2, 3]. Thus, the prevention of osteoporosis should start at an early age both in women and men and should be mainly aimed at reaching the highest possible peak bone mass (PBM) $[4,5]$.

PBM is the maximal mass that can be reached by bone tissue; it is the highest bone mass we attain in life. PBM is achieved within the first years after the age of 20 is reached (between 20 and 30). It determines the possibility of osteoporosis in later years of life, so the occurrence of this disease is more probable in individuals who did not reach optimal bone mass in their period of growth [6].

After maximal bone mineral content (BMC) is reached at the age of 30-35, bone mass starts to decrease, and the process of removing minerals and collagen which are part of bone tissue occurs faster than the creation of new bone tissue. In the case of increased resorption, there is a risk of osteopenia leading to osteoporosis. Therefore, it is highly significant for PBM to reach an optimal level in the period when the skeleton is fully developed. Moreover, the risk of osteoporosis is connected not only with the loss of bone mass, but also with the fact that the bones did not reach optimal peak density, as in this case even a slight loss of bone mass may lead to osteoporosis [7].

Whether or not an optimal level of peak bone mass is reached depends on several factors. It is undoubtedly to a great extent contingent on genetic factors. However, an equally significant role in reaching a high level of PBM is attributed to environmental factors, among which physical activity and diet are seen as the most important $[8,9]$.

Physical activity and appropriate mechanical loading of the skeleton at the early stages of life exert a significant influence on the transformation of bone tissue and help to reach higher peak bone mass, which, in turn, considerably reduces the risk of osteoporosis in later life. In the case of adults, physical activity mainly helps to maintain the previously reached level of bone mass but it may also increase this level (albeit to a low extent, i.e. $1-2 \%)[10]$.

In connection with the above facts, remembering equally that osteoporosis does not initially give any characteristic clinical symptoms, early prevention is very important. This concerns especially young people who, due to unfavourable civilisation changes in lifestyle (mainly the lack of physical activity or low physical activity and improper nutrition), are more and more often at risk for this disease.

In light of the above, the study sought to assess bone mineral content (BMC) and bone mineral density (BMD) in men with 
different levels of physical activity during the period of reaching peak bone mass.

\section{Material and methods}

The study was carried out on 119 men aged 20-22 who demonstrated various levels of physical activity and were reaching peak bone mass. This group included wrestlers $(n=31)$, who presented a high level of physical and sports activity. They started training professionally at a mean age of 12 years, trained for an average of 12 hours per week, and participated in prestigious competitions, e.g. in the Polish Youth Olympic Games, International Polish Championships, or Polish Junior and Senior Championships. The wrestlers examined were current or previous students of the Sports School in Radom. Another group comprised third-year undergraduate male students $(n=88)$ of the Jozef Pilsudski University of Physical Education in Warsaw, University College in Biala Podlaska. Due to the differences in the levels of physical activity, the students were divided into two groups. The first group included physical education students (n $=55)$, while the other group consisted of physiotherapy students $(\mathrm{n}=33)$. The students regularly participated in practical classes included in the study curriculum for 3 years and declared they did not perform regular physical activity outside of the physical education classes at university. In the case of physical education students, this activity lasted 7 hours per week and included classes in gymnastics, athletics, team sports, and swimming. Physiotherapy students devoted 4 hours per week to physical activity such as swimming and movement games and play.

Body height and mass were measured in a conventional manner with an accuracy of $0.1 \mathrm{~cm}$ and $0.1 \mathrm{~kg}$, respectively. BMC $(\mathrm{g})$ and $\mathrm{BMD}\left(\mathrm{g} / \mathrm{cm}^{2}\right)$ were determined in the lumbar spine $\left(\mathrm{L}_{2^{-}}\right.$ $\mathrm{L}_{4}$ ) with the use of Dual Energy X-ray Absorptiometry (DEXA) on the HORIZON Ci device (USA). Also, the body composition of the study participants, that is fat tissue content (\%), muscle mass $(\mathrm{kg})$, and fat-free body mass $(\mathrm{kg})$, was measured with the use of this device. All the measurements were performed in the Physiological Diagnostics Laboratory of the Regional Centre for Research and Development in Biala Podlaska.

Diet composition was assessed on the basis of three individual questionnaire interviews concerning nutrition from the last 24 hours before the study. Interviews regarded two weekdays and one day without classes (Sunday) and were performed by trained interviewers. The size of the portions was assessed with the use of the "Album of products and dishes with various portions" [11]. The intake of energy as well as protein, calcium, and phosphorus from food was calculated using DIETA computer software based on the Polish nutritional tables [12].

The obtained data on the intake of energy and nutrients were compared with the norms of estimated average require- ments (EAR) taking into account the gender, physical activity, body mass, and age of the participants. In order to assess insufficient nutrition, the percentage of individuals (\%) whose food portions did not meet EAR norms was calculated. A high risk (above 50\%) of insufficient nutrition occurs in individuals with low intake below EAR. Intake above EAR means that there is a probability of more than $50 \%$ that the intake of a nutrient is appropriate. The ratio of calcium to phosphorus was calculated and compared with the recommended values computed on the basis of the norms [13].

Data regarding the sports careers of the wrestlers, that is the age at which they started training regularly, their training experience, and weekly training loads (in hours), were collected in a diagnostic survey with a specially designed questionnaire. The questionnaire also included questions concerning risk factors for osteoporosis (environmental, genetic, and health staterelated) which were answered by all the study participants.

The participation of all the individuals was voluntary, and consent was obtained from all the men. Moreover, the project was approved by the Research Ethics Committee of the University of Physical Education in Warsaw. The study is of a longterm character, and the results presented regard the first stage of the research.

Statistical analysis was performed on the basis of one-way analysis of variance (ANOVA) and Tukey's post-hoc tests, where differences at the level of $\mathrm{p}<0.05$ were treated as significant. Normal distribution in subgroups was verified with ShapiroWilk test.

\section{Results}

Table 1 presents the general characteristics of the study participants examined. The groups under investigation turned out to be very similar in terms of body build and composition. None of the parameters examined manifested statistically significant differences.

The current state of bone tissue in the men under investigation is presented in Table 2. Statistical analysis revealed that the highest level of bone mass parameters was found in wrestlers. Mean values of BMC and BMD in this group were $93.18 \mathrm{~g}$ and $1.323 \mathrm{~g} / \mathrm{cm}^{2}$, respectively. The values of both parameters differed significantly from the ones obtained by the students. In the case of physical education students, the difference was at the level of $\mathrm{p}<0.01$, while in physiotherapy students, it was $\mathrm{p}<0.001$, in favour of the wrestlers. Mean values of BMC and BMD in the group of physical education students were at the level of 83.58 $\mathrm{g}$ and $1.112 \mathrm{~g} / \mathrm{cm}^{2}$, while among physiotherapy students, the values were $75.88 \mathrm{~g}$ and $1.097 \mathrm{~g} / \mathrm{cm}^{2}$, respectively.

Also, a statistically significant difference $(\mathrm{p}<0.05)$ was found between the groups of students in the case of mean values

Table 1. General characteristics of the men examined (mean \pm SD)

\begin{tabular}{|c|c|c|c|c|c|c|c|}
\hline GROUP & $\begin{array}{c}\text { Number } \\
(\mathbf{n})\end{array}$ & $\begin{array}{c}\text { Age } \\
(\text { years })\end{array}$ & $\begin{array}{c}\text { Body mass } \\
(\mathbf{k g})\end{array}$ & $\begin{array}{c}\text { Body height } \\
(\mathbf{c m})\end{array}$ & $\begin{array}{c}\text { Fat-free body } \\
\text { mass }(\mathbf{k g})\end{array}$ & $\begin{array}{c}\text { Muscle mass } \\
(\mathbf{k g})\end{array}$ & $\begin{array}{c}\text { Fat tissue } \\
(\%)\end{array}$ \\
\hline Wrestlers & 31 & $20.4 \pm 1.75$ & $79.5 \pm 10.7$ & $175.9 \pm 8.5$ & $63.7 \pm 9.9$ & $64.2 \pm 8.5$ & $17.9 \pm 4.2$ \\
\hline $\begin{array}{c}\text { Physical Education } \\
\text { students }\end{array}$ & 55 & $20.7 \pm 1.41$ & $81.8 \pm 8.5$ & $182.2 \pm 5.7$ & $62.1 \pm 5.9$ & $60.4 \pm 5.7$ & $20.4 \pm 4.6$ \\
\hline $\begin{array}{c}\text { Physiotherapy } \\
\text { students }\end{array}$ & 33 & $20.0 \pm 1.29$ & $85.1 \pm 11.9$ & $180.5 \pm 5.5$ & $60.1 \pm 6.5$ & $58.7 \pm 6.6$ \\
\hline
\end{tabular}


Table 2. Characteristics of bone parameters of the men examined (mean \pm SD)

\begin{tabular}{|c|c|c|c|c|c|c|}
\hline \multirow[b]{2}{*}{ GROUP } & \multirow[b]{2}{*}{ Number ( $n$ ) } & \multirow[b]{2}{*}{$B M C(g)$} & \multirow[b]{2}{*}{$p$} & \multicolumn{2}{|c|}{ BMD } & \multirow[b]{2}{*}{$p$} \\
\hline & & & & $\mathrm{g} / \mathrm{cm}^{2}$ & $\begin{array}{c}\text { As compared to age } \\
(\%)\end{array}$ & \\
\hline Wrestlers ${ }^{A}$ & 31 & $93.18 \pm 14.13$ & $\begin{array}{l}\text { A vs. } B^{* *} \\
\text { A vs. } C^{* * *}\end{array}$ & $1.323 \pm 0.096$ & $107.4 \pm 11.2$ & $\begin{array}{l}\text { A vs. } B^{* *} \\
\text { A vs. } C^{* * *}\end{array}$ \\
\hline Physical Education students $B$ & 55 & $83.58 \pm 11.58$ & $\begin{array}{l}\text { B vs. } A^{* *} \\
\text { B vs. } C^{*}\end{array}$ & $1.112 \pm 0.109$ & $98.2 \pm 9.86$ & B vs. $A^{* *}$ \\
\hline Physiotherapy students C & 33 & $75.88 \pm 9.78$ & $\begin{array}{l}\text { C vs. } A^{* * *} \\
C \text { vs. } B^{*}\end{array}$ & $1.097 \pm 0.095$ & $96.0 \pm 11.9$ & C vs. $A^{* * *}$ \\
\hline
\end{tabular}

${ }^{*}-\mathrm{p}<0.05 ;{ }^{* *}-\mathrm{p}<0.01 ;{ }^{* *}-\mathrm{p}<0.001$.

Table 3. Mean intake of energy, protein, calcium, and phosphorus in the men examined (mean \pm SD)

\begin{tabular}{|c|c|c|c|c|c|c|}
\hline GROUP & Number (n) & $\begin{array}{c}\text { Energy } \\
\text { (kcal) }\end{array}$ & $\begin{array}{l}\text { Protein } \\
\text { (g) }\end{array}$ & $\begin{array}{l}\text { Calcium } \\
\text { (mg) }\end{array}$ & $\begin{array}{l}\text { Phosphorus } \\
\text { (mg) }\end{array}$ & Ca:P \\
\hline Wrestlers & 31 & $\begin{array}{c}2882 \pm 665 \\
(71.8)^{\#}\end{array}$ & $121.3 \pm 33.2(222.4)$ & $862 \pm 389(107.9)$ & $1887 \pm 553(325.4)$ & $1: 2.2$ \\
\hline Physical Education students & 55 & $\begin{array}{c}2964 \pm 552 \\
(86.7)\end{array}$ & $131.4 \pm 36.1(221.2)$ & $782 \pm 368(98.7)$ & $2019 \pm 560(348.1)$ & $1: 2.6$ \\
\hline Physiotherapy students & 33 & $\begin{array}{c}2841 \pm 682 \\
(77.8)\end{array}$ & $133.2 \pm 32.1(226.8)$ & $821 \pm 299(102.7)$ & $2023 \pm 488(348.9)$ & $1: 2.5$ \\
\hline
\end{tabular}

\# - mean percentage of realisation of the norm at the level of estimated average requirement (EAR) for the group are given in brackets.

of BMC. Higher values of this parameter were found in physical education students than in physiotherapy students.

An individual analysis of the results revealed that, according to WHO criteria (Z-score), the research results indicated low BMC with regard to calendar age in as many as 20 participants ( 2 wrestlers, 8 physical education students, and 10 physiotherapy students). The values of this parameter fell within the range of -1.1 to -2.0 .

The analysis of nutrition revealed no significant differences regarding the daily intake of energy, protein, calcium, or phosphorus between individuals from particular groups under investigation. A worrying trend in the dietary intake of protein and phosphorus has been observed, which was well above the level of the group's average demand. Also, the calcium to phosphorus ratio in each of the groups analysed differed from the preferred value (1:0.7) calculated on the basis of standards.

The questionnaire also included questions concerning genetic and lifestyle-related risk factors for osteoporosis. None of the men examined had any cases of osteoporosis in their families. In contrast, previous fractures in various areas of the skeleton resulting from falls were noted both in the group of wrestlers (6) and among students (15). The highest number of fractures (as many as 10) was declared by physiotherapy students.

\section{Discussion}

The very low level of physical activity in society is an alarming phenomenon also in Poland. The lack of physical activity is one of the symptoms of faster ageing and the cause of health loss and numerous diseases of affluence, including osteoporosis. Therefore, the prevention of osteoporosis should start at an early age and be aimed at reaching the highest possible peak bone mass, and it should be continued throughout the life span [14-16].
A positive influence of physical activity on bone metabolism results from stimulating the activity of osteoblasts (bone formation) and inhibiting the activity of osteoclasts (resorption). Therefore, physical activity is perceived as an important factor which determines the level of peak bone mass in the growth period, stabilises bone tissue in adulthood, and regulates its loss in old age. The influence of physical activity on bone tissue is analysed in terms of the effects of gravitation on the skeleton and the influence of direct stimulation of the musculoskeletal system on bone formation and bone remodelling through the exertion of pulsing forces. Everyday physical activity leads to the occurrence of piezoelectric effects in bone tissue which influence the aforementioned processes. It is believed that every type of physical activity during which the bones are loaded many times increases their density in the places where forces are exerted $[17,18]$.

This is in line with the findings of other authors who proved that physical activity in the growth period may lead to a considerable increase in bone mass. It is best if this activity is continued in early adulthood as it considerably increases peak bone mass. In adult life, in turn, it only causes its slight increase in PBM and seems to play a bigger role in preventing early loss of bone mass [19-22].

Already in 1971, Nilsson and Wesflin [23] revealed higher BMD in athletes than in individuals who did not do any sports; however, the reaction to the effort was considerable in the places where the largest forces were exerted. This finding was even more clearly confirmed by the results of screening studies conducted on athletes doing different sports. For instance, higher BMD was revealed in gymnasts whose training was connected with big loads exerted on the musculoskeletal system or in longdistance runners who experienced pulsing forces exerted on the calcaneus, femur shaft, and spine leading to a considerable increase in the mineralisation of these bones. The same correla- 
tions were noted in individuals doing other sports, in whom increased density of loaded bones was observed [24-26].

The above observations lead to the conclusion that sports training is a type of activity which facilitates the proper development of bone tissue to the greatest extent. Similar observations were made in our research where the highest values of BMD and BMC were noted in wrestlers compared to the other two groups. This difference was most visible in the case of physiotherapy students, who demonstrated the lowest levels of physical activity (Tab. 2).

The influence of training on higher values of bone parameters is already well-documented; however, there is a lack of studies concerning the effects of regular physical activity not connected with professional training on these parameters. Currently, young people most often choose a passive way of spending their free time, not taking into account that it is in the period of reaching peak bone mass that insufficient physical activity or its lack may lead to the fact that the level necessary to prevent future loss of bone tissue will not be reached. Therefore, the ability to increase bone mass is one of the most important health benefits of physical activity. Maximising peak bone mass, maintaining its level after this period, and minimising its loss in older age should constitute three recommendations concerning the prevention of osteoporosis and further fractures [27-29].

It seems that young people (and students from the University of Physical Education in particular) should be aware of a positive influence of regular physical activity on the human body, also in terms of reaching peak bone mass. Unfortunately, the results of research on male students of courses in health and exercise sciences are not satisfactory $[30,31]$. The research on bone mineral density carried out among students of the University of Physical Education in Wroclaw $(n=125)$ who were reaching peak bone mass (mean age $=21.9$ years) revealed lower BMD values which could indicate osteopenia in approximately $15 \%$ of the study participants [32]. Similar correlations were noted in our research, which revealed cases of low bone mass both among physical education and physiotherapy students, with BMD values with regard to age at the level of $98.2 \%$ and 96.0\%, respectively.

Positive effects of regular leisure physical activity on an increase in bone mineral density in men reaching its peak value were confirmed by the study of Almstedt HC et al. [33] carried out in 2011. The study revealed that in response to 24-hour resistance training, BMD increased in men who were physically active on an everyday basis, compared to their counterparts who had a passive lifestyle.

Similar correlations were noted in the research by Selma Liberato et al. [34] carried out in 2013 on young men aged 18$25(\mathrm{n}=35)$, which analysed the effects of physical activity and calcium supplementation on bone mineralisation in the lumbar spine. It was concluded that the best effects connected with high mineralisation of this segment of the spine were noted in the case of age-appropriate calcium supplementation and moderate or high-intensity physical activity. Similar correlations were founds in our research. The highest values of BMC and BMD were observed in wrestlers (having the highest level of physical activity) and physical education students (with an average level of physical activity), while physiotherapy students, who declared low levels of physical activity, also demonstrated the lowest values of these parameters, with similar levels of calcium supplementation in all the groups (Tab. 2).

More explicit evidence of a considerable influence of physical activity in the period of reaching peak bone mass can be found in the research conducted on a highly representative sample of young male adults in Sweden $(\mathrm{n}=2384)$ aged 18 who underwent obligatory selection tests required for compulsory military training. It was revealed that regular physical activity was the strongest factor leading to high BMD in the calcaneus, and peak bone mass in this area was reached already at the age of 18 [35].

Apart from physical activity, nutrition (calcium content in a diet and calcium-phosphorus ratio, in particular) is a significant factor which determines reaching the highest peak bone mass. The research indicates a positive influence of physical activity only when it is combined with proper calcium intake.

Appropriate calcium intake is significant in every period of life; however, due to the realisation of a genetic programme regarding peak bone mass, the childhood and adolescence periods are the most important. The role of calcium in the body during growth is reflected in nutritional norms which are at their highest levels in this period [36, 37].

In our research, calcium intake in all the groups under investigation, except for physical education students (98.7\%), exceeded the level of the estimated average requirement for the group but only by $5.3 \%$, which means it was close to the limits of safe intake.

Apart from calcium, bone tissue also includes phosphorus; however, this is not to imply that high intake of this mineral is healthy. While calcium builds the bones, large amounts of phosphorus lead to the loss of bone mass by inhibiting the absorption of calcium from the gastrointestinal tract and by increasing the loss of calcium with urine. Phosphorus is indispensable for bone remodelling but an appropriate phosphorus-calcium ratio needs to be maintained. It is best if the ratio is 1:1 or 1.5:1. Due to the fact that phosphorus is very common in food products, its deficiencies do not generally occur. What seems to be a bigger nutritional problem is its excessive intake.

Similar observations regard the intake of protein. Protein absorbed from food affects bone quality by participating in the synthesis of collagen and other bone matrix proteins. Research results indicate a relationship between protein intake and BMD. Insufficient intake of protein (below the recommended values, i.e. $0.8-1.0 \mathrm{~g} / \mathrm{kg} / \mathrm{month}$ ) may negatively affect BMC by reducing calcium absorption and causing a secondary increase in parathormone concentration. Simultaneously, excessive intake of protein, particularly animal protein, is one of the factors increasing the risk of osteoporosis. An increase in the amount of protein in the diet by $1 \mathrm{~g}$ leads to additional loss of $1 \mathrm{mg}$ of calcium with urine. This is caused by acidifying properties of protein, mainly animal protein [38].

This alarming trend was observed in our research as the mean intake of phosphorus and protein was exceeded in all the groups under investigation. In the case of phosphorus, it was over $240 \%$ while for protein, it was $123 \%$ of the estimated average requirement for the group. Also, the ratio of calcium to phosphorus in all the groups analysed differed from the preferred value (Tab. 3).

\section{Conclusion}

The following conclusions may be drawn from the study:

The best bone mineralisation was observed in the group of wrestlers, who had a high level of physical activity.

It seems that in the absence of statistically significant differences in the diet, the level of physical activity had a decisive impact on the mineralisation of bone tissue in the men examined in the study. 


\section{Acknowledgements}

The study was carried out under research project DS. 284 at Jozef Pilsudski University of Physical Education in Warsaw, Faculty of Physical Education and Sport in Biala Podlaska. The project was financed by the Polish Ministry of Science and Higher Education.

\section{Literature}

1. Lewiecki E.M. (2008). Prevention and treatment of postmenopausal osteoporosis. Obstetrics and Gynecology Clinics of North America 35, 301-315.

2. Cooper C., Cole Z.A., Holroyd C.R., Earl S.C., Harvey N.C. et al. (2011). The IOF CSA Working Group on Fracture Epidemiology. Secular trends in the incidence of hip and other osteoporotic fractures. Osteoporosis International 22, 12771288.

3. Czerwiński E., Boczoń K., Kumorek A. (2012). Epidemiology of osteoporotic fractures. Postępy Nauk Medycznych 3, 206-212. [in Polish]

4. Kanis J.A., Johnell O., Oden A., De Laet C., Mellstrom D. (2004). Epidemiology of osteoporosis and fractures in men. Calcified Tissue International 10, 107-112.

5. Beck B.R., Daly R.M., Singh M.A., Taaffe D.R. (2017). Exercise and Sports Science Australia (ESSA) position statement on exercise prescription for the prevention and management of osteoporosis. Journal of Science and Medicine in Sport 20(5), 438-445.

6. Roy C., Combes C., Drouet C., Glimcher M.J. (2009). Bone mineral: Update on chemical composition and structure. Osteoporosis International 20, 1013-1021.

7. Almeida M. (2012). Aging mechanisms in bone. BoneKEy Reports 1, 102.

8. Bloomfield S.A. (2005). Contributions of physical activity to bone health over the lifespan. Topics in Geriatric Rehabilitation 21(1), 68-76.

9. Morseth B., Emaus N., Jørgensen L. (2011). Physical activity and bone: The importance of the various mechanical stimuli for bone mineral density. A review. Norsk Epidemiologi 20(2), 173-178.

10. Bailey C.A., Kukuljan S., Daly R.M. (2010). Effects of lifetime loading history on cortical bone density and its distribution in middle-aged and older men. Bone 47(3), 673-80.

11. Szponar L., Wolnicka K., Rychlik E. (2008). Album of photographs of food products and dishes. National Food and Nutrition Institute, Warsaw. [in Polish]

12. Kunachowicz H., Nadolna I., Przygoda B., Iwanow K. (2005). Tables of food composition and nutritional value. Medical Journal PZWL, Warsaw. [in Polish]

13. Jarosz M. (ed.) (2017). Nutrition standards for the Polish population. National Food and Nutrition Institute, Warsaw. [in Polish]

14. Drygas W. (2006). Does sedentary lifestyle still pose a threat to the health of the Polish society? Medycyna Sportowa 22, 111-116. [in Polish]

15. Cauley J.A. (2013). Public health impact of osteoporosis. Journal of Gerontology 68, 1243-1251.

16. Grabara M. (2017). Hatha yoga as a form of physical activity in the context of lifestyle disease prevention. Polish Journal of Sport and Tourism 24, 65-78.

17. Korhonen M.T., Mero A.A., Alen M., Sipila S., Hakkinen K. et al. (2009). Biomechanical and skeletal muscle deter- minants of maximum running speed with aging. Medicine Science in Sports Exercise 41(4), 844-856.

18. Petersen B.A., Hastings B., Gottschall J.S. (2017). Low load, high repetition resistance training program increases bone mineral density in untrained adults. Journal of Sports Medicine and Physical Fitness 57(1-2), 70-76.

19. Hagman M., Wolff Helge E., Hornstrup T., Fristrup B., Nielsen J.J. et al. (2018). Bone mineral density in lifelong trained male football players compared with young and elderly untrained men. Journal of Sport and Heath Science 7, 159-168.

20. Silver T., Ellerbroek A., Knofo S., Peacock C.A., Tartar J. et al. (2018). High and low impact physical activity positively influences female bone density. Journal of Exercise and $\mathrm{Nu}$ trition 1(5), 1-4.

21. Gunter K.B., Almstedt H.C., Janz K.F. (2012). Physical activity in childhood may be the key to optimizing lifespan skeletal health. Exercise and Sport Sciences Reviews 40(1), 13-21.

22. Tveit M., Rosengren B.E., Nilsson J.A., Ahlborg H.G., Karlsson M.K. (2012). Bone mass following physical activity in young years: A mean 39-year prospective controlled study in men. Osteoporosis International 2012 DOI: 10.1007/ s00198-012-2081-z.

23. Nilsson B.E., Wesflin N.E. (1971). Bone density in athletes. Clinical Orthopaedics and Related Research 77, 179-182.

24. Nilsson M., Ohlsson C., Oden A., Mellstrom D., Lorentzon M. (2012). Increased physical activity is associated with enhanced development of peak bone mass in men: A five-year longitudinal study. Journal of Bone and Mineral Research 27(5), 1206-1214.

25. Šolaja A., Šolaja M. (2017). Differences in the parameters of calcaneal bone mineral density between elite track and field athletes, elite handball players and sedentary male controls. Facta Universitatis. Series: Physical Education and Sport 15(2), 261-270.

26. Antonio J., Leaf A., Carson C., Ellerbroek A., Silver T. et al. (2018). Bone mineral density in competitive athletes. Journal of Exercise and Nutrition 1(2), 1-11.

27. Neville C.E., Murray L.J., Boreham C.A., Gallagher A.M., Twisk J. et al. (2002). Relationship between physical activity and bone mineral status in young adults: The Northern Ireland Young Hearts Project. Bone 30(5), 792-798.

28. Ma H., Leskinen T., Alen M., Cheng S., Sipila S. et al. (2009). Long-term leisure time physical activity and properties of bone: A twin study. Journal of Bone and Mineral Research 24(8), 1427-1433.

29. Gomez-Cabello A., Ara I., Gonzalez-Ageuero A., Casajus J.A., Vicente-Rodriguez G. (2012). Effects of training on bone mass in older adults. Sports Medicine 42, 301-325.

30. Mędrala-Kuder E. (2011). Evaluation of the lifestyle of students of physiotherapy and technical \& computer science based on their diet and physical activity. Roczniki Państwowego Zakładu Higieny 62(3), 315-318. [in Polish]

31. Reeves B., Barwick E., Maghrabi P. (2018). Physical fitness level of first year exercise science students. Journal of Exercise and Nutrition 1(5).

32. Konieczna A., Demidaś A., Berner E. (2004). The estimation of the bone mineral density in students aged 20-29 years. Acta Bio-Optica et Informatica Medica 10, 87-90. [in Polish]

33. Almstedt H.C., Canepa J.A., Ramirez D.A., Shoepe T.C. (2011). Changes in bone mineral density in response to 24 
weeks of resistance training in college-age men and women. Journal of Strength Conditioning Research 25(4), 1098-1103.

34. Liberato S.C., Bressan J., Hills A.P. (2013). The role of physical activity and diet on bone mineral indices in young men: A cross-sectional study. Journal of the International Society of Sports Nutrition 10, 43.

35. Pettersson U., Nilsson M., Sundh V., Mellstrom D., Lorentzon M. (2010). Physical activity is the strongest predictor of calcaneal peak bone mass in young Swedish men. Osteoporosis International 21(3), 447-455.

36. Ondrak K.S., Morgan D.W. (2007). Physical activity, calcium intake and bone health in children and adolescents. Sports Medicine 37(7), 587-601.
37. Alghadir A.H., Gabr S.A., Al-Eisa E. (2015). Physical activity and lifestyle effects on bone mineral density among young adults: Sociodemographic and biochemical analysis. Journal of Physical Therapy Science 27(7), 2261-227.

38. Ito S., Ishida H., Uenishi K., Murakami K., Sasaki S. (2011). The relationship between habitual dietary phosphorus and calcium intake, and bone mineral density in young Japanese women: A cross-sectional study. Asia Pacific Journal of Clinical Nutrition 20(3), 411-417.

Submitted: December 3, 2018.

Accepted: February 1, 2019. 